\title{
Factors Influencing Public Knowledge and Willingness to Participate in Biomedical Research in Jordan: A National Survey
}

This article was published in the following Dove Press journal: Patient Preference and Adherence

\author{
Rana Abu Farha $\mathbb{D}^{\prime}$ \\ Karem H Alzoubi iD ${ }^{2}$ \\ Omar F Khabour iD ${ }^{3}$ \\ Tareq L Mukattash (iD ${ }^{2}$ \\ 'Department of Clinical Pharmacy and \\ Therapeutics, Faculty of Pharmacy, \\ Applied Science Private University, \\ Amman II93I, Jordan; ${ }^{2}$ Department of \\ Clinical Pharmacy, Faculty of Pharmacy, \\ Jordan University of Science and \\ Technology, Irbid 22110, Jordan; \\ ${ }^{3}$ Department of Medical Laboratory \\ Sciences, Faculty of Applied Medical \\ Sciences, Jordan University of Science and \\ Technology, Irbid 22। I0, Jordan
}

Purpose: Recruitment of adequate numbers of research participants is important for advancement in biomedical fields. Awareness and knowledge of the population about biomedical research are expected to enhance willingness to participate in such research. Therefore, in the current study, participants' awareness, knowledge, and willingness to participate in scientific research in Jordan were examined.

Methods: This was a survey-based, cross-sectional study conducted from December 2019 to February 2020 among the public in Jordan. After written informed consent had been obtained from study participants, a structured questionnaire was used to survey research participants. The final questionnaire contained three parts: part I was about demographics and general information, part II assessed participants' awareness and willingness to participate in biomedical research, and part III assessed participants' knowledge about biomedical research studies.

Results: A total of 2,000 subjects agreed to participate, of which $67.4 \%$ were female $(n=1339)$. More than half the respondents were aware of biomedical research $(58.6 \%)$, of which $18.1 \%$ had previously participated in biomedical research. In addition, $55.5 \%$ reported that they were willing to participate in biomedical research, while a lower proportion (31.1\%) were willing to volunteer in a clinical trial. The overall knowledge of participants about biomedical research was deemed moderate (total score 12.9 out of 20). Finally, willingness to participate in biomedical research was associated with being male, being married, having a biomedicine-related degree, and higher knowledge score.

Conclusion: A majority of Jordanians had moderate levels of awareness and knowledge about biomedical research. Such factors as sex, type of education, and knowledge contribute to willingness to participate in biomedical research.

Keywords: willingness, knowledge, biomedical research, public, Jordan

\section{Introduction}

Biomedical research is considered an important element in discovering new knowledge or revising current knowledge. ${ }^{1}$ It has an important role in the development of scientific literature and the advancement of health care provided to individuals and communities. $^{2}$ Advances of biomedical research are highly dependent on the successful recruitment and participation of human subjects. Unfortunately, human participation in different types of biomedical research is inadequate and considered one of the main challenges facing researchers in the biomedical field. ${ }^{3,4}$

Inadequate involvement in biomedical research may give rise to several challenges, including insufficient sample size, which may affect the power of the study,
Correspondence: Rana Abu Farha Department of Clinical Pharmacy and Therapeutics, Faculty of Pharmacy, Applied Science Private University, Amman II93I, Jordan

Tel +962 6-560-9957 ext 1496

Fax +9625232899

Email abufarharana@yahoo.com
Patient Preference and Adherence 2020:14 I373-1379

1373 
increasing the likelihood of increasing type II error, and adversely influencing the generalizability of results to the general population. ${ }^{5,6}$ Therefore, to improve the success of biomedical research, it is vital to identify and recognize factors influencing the willingness of an eligible individual to participate in biomedical research. ${ }^{7}$

Lack of public awareness about biomedical research is considered one of the main factors hindering subjects' participation in biomedical research. ${ }^{8}$ Awareness about the anticipated benefits of taking part in research, possible risk, and understanding of what is required of participants may all influence their willingness to participate in biomedical research. ${ }^{8}$ Additionally, sociodemographic factors, including education, income, and religion, may influence participants' decision to provide their consent and to participate in biomedical research. ${ }^{9-12}$

There have been few studies that have evaluated awareness of participants about biomedical research and factors affecting their willingness to participate in biomedical research in the Middle East, ${ }^{13,14}$ and none has been conducted within the Jordanian community. Accordingly, the aim of the current study was to assess the knowledge and awareness of public in Jordan about biomedical research and to determine factors associated with their participation in various types of biomedical research studies.

\section{Methods}

This was a cross-sectional study conducted from December 2019 to February 2020 among the public in Jordan. Convenience sampling was used. Adults $(\geq 18$ years old) from both sexes were approached in public places, at gatherings, and at their homes to fill out a selfadministered questionnaire. Written informed consent was obtained before questionnaire administration from each participant, as requested by the Institutional Review Board of Jordan University of Science and Technology (approval23/128/2019). A detailed explanation of the study protocol was provided prior to handing the questionnaire to the participants.

We used $\mathrm{G}^{*}$ Power software version 3.1.9.7 to calculate the sample size, resulting in a significance level of 0.05 , power of 0.95 , small-effect size of 0.15 , and minimum number of subjects of 1,979. Based on an anticipated dropout rate of $10 \%$, the target number of participants was 2,100 . We performed an analysis of the data from 2,000 subjects.

The study instrument was developed via brainstorming within the research team and by referring to previous literature. ${ }^{15,16}$ The initial draft of the questionnaire was facevalidated via a group of experts, where input was taken and the questionnaire adjusted accordingly. Thereafter, the questionnaire was pilot-tested, where feedback from 30 participants who had been encouraged to provide comments about the clarity and comprehensibility of each item of the questionnaire was taken. Data from the pilot sample were not included in the final analysis.

The instrument was composed of three parts. Part I was about demographics and general information, including age, sex, education, employment, income, marital status, residence, religion, and general health status. Part II assessed participants' awareness of and willingness to participate in biomedical research. In this section, participants were asked six questions to assess any previous participation in medical research and their future willingness to participate in medication research with different objectives (shown in Table 1). Part III assessed participants' knowledge about biomedical research studies, and

Table I Participants' awareness of and willingness to participate in medical research $(n=2,000)$

\begin{tabular}{|c|c|}
\hline & n (\%) \\
\hline $\begin{array}{l}\text { Have you heard about medical research? } \\
\text { - Yes } \\
\text { - No }\end{array}$ & $\begin{array}{l}\text { I, I } 64 \text { (58.6\%) } \\
822(4 \mathrm{I} .4 \%)\end{array}$ \\
\hline $\begin{array}{l}\text { Have you participated in any medical } \\
\text { research? } \\
\text { - Yes } \\
\text { - No }\end{array}$ & $\begin{array}{l}361(18.1 \%) \\
1,63 \mid(81.9 \%)\end{array}$ \\
\hline $\begin{array}{l}\text { Are you willing to participate in medical } \\
\text { research? } \\
\text { - Yes } \\
\text { - No/unsure }\end{array}$ & $\begin{array}{l}\text { I, } 107(55.5 \%) \\
886(44.4 \%)\end{array}$ \\
\hline $\begin{array}{l}\text { Are you willing to have new drugs tested on } \\
\text { you? } \\
\text { - Yes } \\
\text { - No/unsure }\end{array}$ & $\begin{array}{l}620(31.1 \%) \\
1,375(68.9 \%)\end{array}$ \\
\hline $\begin{array}{l}\text { Are you willing to have approved drugs tested } \\
\text { on you? } \\
\text { - Yes } \\
\text { - No/unsure }\end{array}$ & $\begin{array}{l}913(46.1 \%) \\
1,069(53.9 \%)\end{array}$ \\
\hline $\begin{array}{l}\text { Are you willing to allow any of your family } \\
\text { member to participate in any medical } \\
\text { research? } \\
\text { - Yes } \\
\text { - No/unsure }\end{array}$ & $\begin{array}{l}840(42.2 \%) \\
\mathrm{I}, 149(57.8 \%)\end{array}$ \\
\hline
\end{tabular}


Table 2 Assessment of study-participant knowledge about medical research studies $(n=2,000)$

\begin{tabular}{|c|c|}
\hline & $\begin{array}{l}\text { Correct answer, } \\
\text { n (\%) }\end{array}$ \\
\hline Medical research is limited to survey studies ${ }^{\mathrm{a}}$ & $883(44.6 \%)$ \\
\hline Participants' consent is required only in medical research involving drug treatment ${ }^{\mathrm{a}}$ & I,527 (76.9\%) \\
\hline Filling survey on patients' opinions about healthcare topics is considered a medical research ${ }^{\mathrm{b}}$ & I,527 (76.9\%) \\
\hline Experiments on animals is considered medical research ${ }^{\mathrm{b}}$ & $1,003(50.6 \%)$ \\
\hline Studies to test new drugs or procedures on humans is considered medical research ${ }^{\mathrm{b}}$ & $1,23 \mathrm{I}(62.2 \%)$ \\
\hline Observational studies to determine risk factors of diseases is considered medical research ${ }^{\mathrm{b}}$ & $1,366(68.9 \%)$ \\
\hline Observationals to assess the safety of medication on patient health is considered medical research ${ }^{\text {b }}$ & $\mathrm{I}, 403(70.8 \%)$ \\
\hline Testing new devices on humans is considered medical research ${ }^{\mathrm{b}}$ & $\mathrm{I}, 22 \mathrm{I}(6 \mathrm{I} .4 \%)$ \\
\hline Ethical guidelines are present to regulate the conduct of medical research ${ }^{b}$ & $1,233(62.1 \%)$ \\
\hline Researchers can recruit patients/participants without their approval ${ }^{\mathrm{a}}$ & $\mathrm{I}, 480(74.2 \%)$ \\
\hline Participants can withdraw freely from any medical research at any time ${ }^{\mathrm{b}}$ & 981 (49.2\%) \\
\hline Confidentiality of personal information is essential to know about before giving consent to participate in a study ${ }^{\mathrm{b}}$ & I,8I3 (9I.I\%) \\
\hline Anticipated benefits are essential to know about before giving consent to participate in a study ${ }^{\mathrm{b}}$ & $1,689(85.0 \%)$ \\
\hline Foreseeable risks are essential to know about before giving consent to participate in a study ${ }^{b}$ & I,627 (82.0\%) \\
\hline Alternative procedures or courses of treatment are essential to know about before giving consent to participate in the study ${ }^{b}$ & $1,490(72.1 \%)$ \\
\hline Research aims are essential to know about before giving consent to participate in a study ${ }^{b}$ & I,588 (80.2\%) \\
\hline The voluntary nature of participation is essential to know about before giving consent to participate in a study ${ }^{\mathrm{b}}$ & $1,425(64.7 \%)$ \\
\hline Possible compensation is essential to know about before giving consent to participate in a study ${ }^{\mathrm{b}}$ & $940(47.6 \%)$ \\
\hline The right to withdraw and its consequence are essential to know about before giving consent to participate in the study ${ }^{\mathrm{b}}$ & I, $194(60.4 \%)$ \\
\hline The number of participants needed is essential to know about before giving consent to participate in the study ${ }^{\mathrm{a}}$ & $575(29.0 \%)$ \\
\hline Knowledge score, mean \pm SD (out of 20 ) & $12.9 \pm 3.8$ \\
\hline
\end{tabular}

Notes: ${ }^{a}$ False; ${ }^{b}$ true.

included 20 items, as shown in Table 2. For each correct item, the participant gained one point, while in the case of incorrect recognition they gained no points. Then, a knowledge score out of 20 was calculated for each participant. Overall knowledge scores were treated according to a quartile scale, where the third and fourth quartiles $(<10)$ were considered inadequate knowledge, the second $(10-<15)$ considered moderate knowledge, and the first $(\geq 15)$ good knowledge.

Data were analyzed using SPSS version 22. The descriptive analysis was undertaken using means and standard deviations for continuous variables and percentages for qualitative variables. Checking for data normality was carried out using the Shapiro-Wilk test (with $P \geq 0.05$ indicating a normally distributed continuous variable). Screening of factors affecting participants' willingness to participate in biomedical research was carried out using univariate and multivariate logistic regression. Following univariate logistic regression analysis, any variables found to be significant at the single-predictor level $(P<0.25)$ were entered into the multiple logistic regression analysis to explore those that were significantly and independently associated with participants' willingness to participate in biomedical research. Variables were selected after checking their multicollinearity, where tolerance values $>0.1$ and variance inflation-factor values $<10$ were checked to indicate the absence of multicollinearity among the independent variables in regression analysis. $P<0.05$ was considered statistically significant.

\section{Results}

The mean age of the sample was $29.1 \pm 10.3$ years (Table 3 ). Around two-thirds of participants were female $(n=1,339$, $67.4 \%$ ). Additionally, almost half the participants were married $(\mathrm{n}=913,45.8 \%)$. Most $(1762,88.9 \%)$ had a personal income of $<\mathrm{JD} 500$. Around half the participants had a bachelor's or postgraduate degree $(n=948,47.7 \%)$, with few having a biomedicine-related degree $(\mathrm{n}=206,10.4 \%)$. Participants who were studying made up $32.3 \%$ of the sample ( $n=642$ ), while the remaining were working full-time, parttime, retired, self-employed, homemaking, or looking for a job. Most of the participants were Jordanian $(n=1,904$, 95.4\%), Muslim (1,967, 98.4\%), and living outside Amman $(\mathrm{n}=1,820,91.4 \%)$.

With regard to participants' health status (Figure 1), $45.6 \%(\mathrm{n}=910)$ believed that their general health was excellent and $52.4 \%(\mathrm{n}=1,047)$ reported their general health to be good, with only $2.0 \%(n=40)$ stating they were in poor 
Table 3 Demographic characteristics of the study sample at baseline $(n=2000)$

\begin{tabular}{|c|c|c|}
\hline & $\begin{array}{l}\text { Mean } \\
\text { (SD) }\end{array}$ & n (\%) \\
\hline Age (years) & $29.1(10.3)$ & \\
\hline $\begin{array}{l}\text { Sex } \\
\text { - Female } \\
\text { - Male }\end{array}$ & & $\begin{array}{l}\text { I,339 (67.4\%) } \\
648(32.6 \%)\end{array}$ \\
\hline $\begin{array}{l}\text { Education } \\
\text { - Low (school or lower) } \\
\text { - High (university or higher) }\end{array}$ & & $\begin{array}{l}\text { I,040 (52.3\%) } \\
948(47.7 \%)\end{array}$ \\
\hline $\begin{array}{l}\text { Employment } \\
\text { - Working full-time } \\
\text { - Working part-time } \\
\text { - Retired } \\
\text { - Self-employed } \\
\text { - Homemaking/caregiving } \\
\text { - Studying } \\
\text { - Looking for work }\end{array}$ & & $\begin{array}{l}560(28.6 \%) \\
115(5.8 \%) \\
51(2.6 \%) \\
97(4.9 \%) \\
304(15.3 \%) \\
642(32.3 \%) \\
211(10.6 \%)\end{array}$ \\
\hline $\begin{array}{l}\text { Personal income } \\
-\quad<\mathrm{D} 500 \text { month } \\
-\quad>J D 500 \mathrm{JD}\end{array}$ & & $\begin{array}{l}1,762(88.9 \%) \\
219(11.1 \%)\end{array}$ \\
\hline $\begin{array}{l}\text { Marital status, } \mathbf{n}(\%) \\
\text { - Married } \\
\text { - Nont married (single, divorced, } \\
\text { widowed) }\end{array}$ & & $\begin{array}{l}913(45.8 \%) \\
1,079(54.2 \%)\end{array}$ \\
\hline $\begin{array}{l}\text { Religion } \\
\text { - Muslim } \\
\text { - Christian } \\
\text { - Other }\end{array}$ & & $\begin{array}{l}19,67(98.4 \%) \\
20(1.0 \%) \\
11(0.6 \%)\end{array}$ \\
\hline $\begin{array}{l}\text { Residence } \\
\text { - Amman } \\
\text { - Other }\end{array}$ & & $\begin{array}{l}|7|(8.6 \%) \\
\mid, 820(91.4 \%)\end{array}$ \\
\hline $\begin{array}{l}\text { Biomedicine-related degree } \\
\text { - Yes } \\
\text { - No }\end{array}$ & & $\begin{array}{l}206(10.4 \%) \\
\text { I,768 (89.6\%) }\end{array}$ \\
\hline
\end{tabular}

Note: US\$I = JD0.7I.

health. A majority reported not having any long-term disability $(\mathrm{n}=1,927,96.7 \%)$ or chronic comorbidity $(\mathrm{n}=1,863$, 95.0\%). On awareness about biomedical research and their willingness to participate in such research (Table 1), responses demonstrated that more than half had heard about biomedical research $(\mathrm{n}=1,164,58.6 \%)$, and only $18.1 \%(\mathrm{n}=361)$ had participated in biomedical research. With regard to willingness to participate in biomedical research, $55.5 \%(\mathrm{n}=1,107)$ reported that they were willing, while fewer were willing to have new drugs $(\mathrm{n}=630,31.1 \%)$ tested on them or have approved drugs tested on them
( $\mathrm{n}=913,46.1 \%)$. On the other hand, $42.2 \%$ of participants $(n=840)$ revealed that they were willing to allow their family members to participate in biomedical research.

For participants' knowledge about biomedical research (Table 2), responses demonstrated that more than half knew the correct answers to the statements, apart from four statements. The first statement was "Biomedical research is limited to survey studies", where only $44.6 \%$ $(\mathrm{n}=883)$ knew that this was false. The second statement was "Participants can withdraw freely from any biomedical research at any time", where only $49.2 \%(\mathrm{n}=981)$ knew that they could. Additionally, 47.6\% ( $\mathrm{n}=940)$ knew that "Possible compensation is essential to know about before giving consent to participate in a study". Finally, only $29.0 \%$ of participants $(n=575)$ knew that the number of participants needed was not essential to know about before giving consent to participate. The overall knowledge score (out of 20) was $12.9 \pm 3.8$. Univariate and multivariate logistic regression analysis of factors affecting participants' willingness to participate in biomedical research emphasized that being male, being married, having a biomedicine-related degree, and higher knowledge score resulted in significantly higher willingness to participate in biomedical research $(P<0.05$, Table 4$)$.

\section{Discussion}

In the current study, participants' awareness, knowledge of, and willingness to participate in biomedical research in Jordan were examined. The results showed that the majority were aware of biomedical research and willing to participate in such studies. In addition, about a third were willing to participate in clinical studies that involved drug testing. The overall knowledge of participants about biomedical research was moderate.

Biomedical research covers areas of science that include examining biological process, etiology of diseases, preventive medicine, medication discovery and testing, management of diseases, and others. It is a multidisciplinary area that involves researchers from both health and basic sciences and an essential area for the discovery of new medicines and therapies for diseases. Advancement in biomedical research requires many research participants. In this case, the awareness and knowledge of the population about biomedical research are expected to enhance participation in biomedical and health-related studies. ${ }^{17,18}$

The findings showed that more than half the surveyed participants were aware (58.6\%) of biomedical research and 


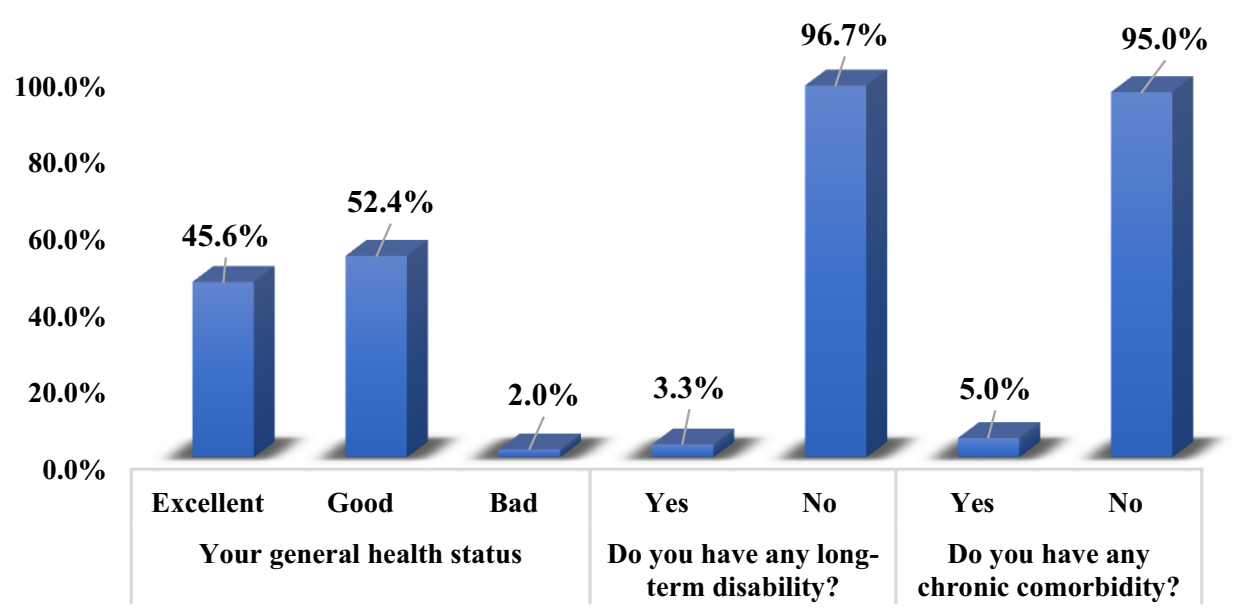

Figure I Participants' health status $(n=2,000)$.

willing $(55 \%)$ to participate in same. Such findings are similar to those reported from several studies in other countries. For example, in a study conducted in Saudi Arabia, about $69 \%$ reported a positive attitude toward biomedical research. ${ }^{14}$ In the UK, a majority of participants (61\%) were positive toward participation and willing to donate their blood for biomedical research. ${ }^{19}$ In the US studies, about $64 \%$ of those surveyed had good awareness about biomedical research ${ }^{20}$ and about $46 \%$ were willing to participate. ${ }^{21}$ However, higher rates of willingness to participate in biomedical research have been reported in Tunisian $(80 \%)$ and Swedish $(86 \%)$ studies. ${ }^{9,22}$ The present study showed that about $31 \%$ were willing to volunteer in clinical trials involving drug testing. Willingness to participate in clinical studies is expected to be low compared to other types of biomedical research. ${ }^{23-25}$ Lower percentages to volunteer in clinical studies were shown in the Tunisian study (38\%), ${ }^{9}$ and a report from the US (32\%). ${ }^{26}$

In the current study, willingness to participate in biomedical research was associated with being male, being married, having a biomedicine-related degree, and higher knowledge scores. In a study from Taiwan, male respondents and those with a biomedical degree or whose household family members had one were more likely to participate in biomedical research. ${ }^{10}$ Sex has also been reported to be a factor in participation in biomedical research in studies conducted in UK and US. ${ }^{27,28}$ In the present study, knowledge of participants about biomedical research aspects was rated as moderate (score 12.9 out of 20). Strong association between willingness to participate in biomedical research and knowledge was reported. Knowledge about biomedical research has been shown strongly to influence willingness to participate. $^{29}$ In an Italian study, 52\% of respondents had knowledge about biomedical research, which was reflected in their attitude to participate in biomedical studies. ${ }^{30}$ Enhancing knowledge of research subjects has been shown to improve willingness to participate in clinical research among African Americans. In addition, level of education was a factor that contributed to participation in genetic research in the US. ${ }^{31}$ The present study showed that age was not among the factors influencing participation in biomedical research. Previous studies showed that age contributed significantly to attitudes toward participation. 9,19-21 This could be due to the nature of the participants in the current study, where the majority were young, healthy, and well educated. Notably, such a sample reflected the general characteristics of the population, with median population age of 23.8 years and a literacy rate of $>99 \%{ }^{32}$ More studies on factors that contribute to willingness to participate in research with a broad age-group are recommended to be done in the studied population. Finally, increasing awareness and knowledge of Jordanians about biomedical research might significantly improve willingness to participate in research studies. This could be achieved via inclusion of topics related to biomedical research awareness within school and university curricula. The use of directed social media is another tool recommended to increase public awareness about biomedical research participation.

\section{Conclusion}

The majority of Jordanians had acceptable levels of awareness and knowledge about biomedical research. Such factors as sex, type of education, and knowledge contributed to willingness to participate in biomedical research. 
Table 4 Assessment of factors affecting participants' willingness to participate in medical research $(n=2,000)$

\begin{tabular}{|c|c|c|c|c|c|c|}
\hline & \multicolumn{6}{|c|}{ Willingness to participate $(0$, no; I, yes) } \\
\hline & OR & $95 \% \mathrm{Cl}$ & $P$-value ${ }^{\#}$ & OR & $95 \% \mathrm{Cl}$ & $P$-value $\$$ \\
\hline Age (years) & 1.010 & $1.001-1.018$ & 0.032 & 0.988 & $0.947-1.002$ & 0.082 \\
\hline $\begin{array}{l}\text { Sex } \\
\text { - Female } \\
\text { - Male }\end{array}$ & $\begin{array}{l}\text { Reference } \\
\text { I.192 }\end{array}$ & $0.985-|.44|$ & 0.071 & 1.281 & $1.010-1.626$ & $0.04 I^{*}$ \\
\hline $\begin{array}{l}\text { Education } \\
\text { - Low (school or lower) } \\
\text { - High (university or higher) }\end{array}$ & $\begin{array}{l}\text { Reference } \\
1.412\end{array}$ & $1.181-1.688$ & $<0.001$ & 1.165 & $0.934-1.453$ & 0.176 \\
\hline $\begin{array}{l}\text { Personal income } \\
\text { - }<\text { JD500/month } \\
\text { - }>\text { JD500month }\end{array}$ & $\begin{array}{l}\text { Reference } \\
1.800\end{array}$ & $1.335-2.427$ & $<0.001$ & 1.259 & $0.876-1.808$ & 0.213 \\
\hline $\begin{array}{l}\text { Marital status, n (\%) } \\
\text { - Married } \\
\text { - Nont married (single, divorced, widowed) }\end{array}$ & $\begin{array}{l}\text { Reference } \\
0.669\end{array}$ & $0.559-0.800$ & $<0.001$ & 0.646 & $0.489-0.853$ & $0.002^{*}$ \\
\hline $\begin{array}{l}\text { Religion } \\
\text { - Muslim } \\
\text { - Other }\end{array}$ & $\begin{array}{l}\text { Reference } \\
0.573\end{array}$ & $0.279-1.176$ & 0.129 & 0.666 & $0.280-1.583$ & 0.357 \\
\hline $\begin{array}{l}\text { Residence } \\
\text { - Amman } \\
\text { - Other }\end{array}$ & $\begin{array}{l}\text { Reference } \\
0.907\end{array}$ & $0.660-1.245$ & 0.545 & - & - & - \\
\hline $\begin{array}{l}\text { Nationality } \\
\text { - Jordanian } \\
\text { - Others }\end{array}$ & $\begin{array}{l}\text { Reference } \\
0.642\end{array}$ & $0.421-0.980$ & 0.040 & 0.834 & $0.493-1.410$ & 0.498 \\
\hline $\begin{array}{l}\text { Biomedicine-related degree } \\
\text { - Yes } \\
\text { - No }\end{array}$ & $\begin{array}{l}\text { Reference } \\
0.777\end{array}$ & $0.587-1.044$ & 0.094 & 0.673 & $0.473-0.957$ & $0.027^{*}$ \\
\hline Knowledge score & 1.169 & $1.136-1.203$ & $<0.001$ & 1.161 & $1.126-1.197$ & $<0.001 *$ \\
\hline
\end{tabular}

Notes: ${ }^{*}$ Using simple logistic regression; ${ }^{\$}$ using multiple logistic regression; ${ }^{*} P<0.05$.

\section{Ethics Approval and Informed Consent}

Written informed consent was obtained before questionnaire administration from each participant, as requested by the Institutional Review Board of Jordan University of Science and Technology (approval 23/128/2019).

\section{Funding}

Work on this project was supported by grant 5R25TW010026-02 from the Fogarty International Center of the US National Institutes of Health.

\section{Disclosure}

Non-financial competing interests. The authors report no other possible conflicts of interest for this work.

\section{References}

1. Amar-Singh H, Bakar AA, Sararaks S. Clinical research Centre Perak (CRC Perak) and Institute for Health Systems Research (IHSR), Malaysia. The Medical Research Handbook. 2008.

2. Barbosa D. Importância da pesquisa clínica para a prática na área de saúde. Acta Paul Enferm. 2010;23(1):vii-vii. doi:10.1590/S010321002010000100001

3. Galea S, Tracy M. Participation rates in epidemiologic studies. Ann Epidemiol. 2007;17(9):643-653. doi:10.1016/j.annepidem.2007.03.013

4. Morton LM, Cahill J, Hartge P. Reporting participation in epidemiologic studies: a survey of practice. Am J Epidemiol. 2006;163 (3):197-203. doi:10.1093/aje/kwj036

5. Quinn G, Keough M. Statistical hypothesis testing. Exp Des Data Anal Biologists. 2002;2002:32-39.

6. Faber J, Fonseca LM. How sample size influences research outcomes. Dental Press J Orthod. 2014;19(4):27-29. doi:10.1590/21769451.19.4.027-029.ebo

7. Burns KE, Magyarody N, Jiang D, Wald R. Attitudes and views of the general public towards research participation. Intern Med J. 2013;43 (5):531-540. doi:10.1111/j.1445-5994.2011.02433.x 
8. Chu SH, Kim EJ, Jeong SH, Park GL. Factors associated with willingness to participate in clinical trials: a nationwide survey study. BMC Public Health. 2015;15(1):10. doi:10.1186/s12889-014-1339-0

9. Bouida W, Grissa MH, Zorgati A, et al. Willingness to participate in health research: tunisian survey. BMC Med Ethics. 2016;17(1):47. doi:10.1186/s12910-016-0131-3

10. Liu H-E, Li M-C. Factors influencing the willingness to participate in medical research: a nationwide survey in Taiwan. PeerJ. 2018;6: e4874. doi: 10.7717 /peerj.4874

11. Browne JL, Rees CO, van Delden JJ, et al. The willingness to participate in biomedical research involving human beings in lowand middle-income countries: a systematic review. Trop Med Int Health. 2019;24(3):264-279. doi:10.1111/tmi.13195

12. Dainesi SM, Goldbaum M. Reasons behind the participation in biomedical research: a brief review. Rev Bras Epidemiol. 2014;17:842-851. doi:10.1590/1809-4503201400040004

13. Tohid H, Choudhury SM, Agouba S, et al. Perceptions and attitudes to clinical research participation in Qatar. Contemp Clin Trials Commun. 2017;8:241-247. doi:10.1016/j.conctc.2017.10.010

14. Al Jumah M, Abolfotouh M, Alabdulkareem LB, et al. Public attitude towards biomedical research at outpatient clinics of King Abdulaziz medical city, Riyadh, Saudi Arabia. East Mediterr Health J. 2011;17 (6):536-545. doi:10.26719/2011.17.6.536

15. Choudhury S, Pradhan R, Dubey L, et al. Knowledge and perception regarding clinical trials among doctors of government medical colleges: a questionnaire-based study. Perspect Clin Res. 2016;7 (2):94-99. doi:10.4103/2229-3485.179433

16. AL-Tannir MA, El-Bakri N, Abu-Shaheen AK, Diemert DJ. Knowledge, attitudes and perceptions of Saudis towards participating in clinical trials. PLoS One. 2016;11(2):e0143893. doi:10.1371/journal.pone. 0143893

17. Hill EM, Turner EL, Martin RM, Donovan JL. "Let's get the best quality research we can": public awareness and acceptance of consent to use existing data in health research: a systematic review and qualitative study. BMC Med Res Methodol. 2013;13(1):72. doi:10.1186/1471-2288-13-72

18. Marriott LK, Cameron WE, Purnell JQ, et al. Let's get healthy! Health awareness through public participation in an education and research exhibit. Prog Community Health Partnersh. 2012;6 (3):331-337. doi:10.1353/cpr.2012.0041

19. Treweek S, Doney A, Leiman D. Public attitudes to the storage of blood left over from routine general practice tests and its use in research. J Health Serv Res Policy. 2009;14(1):13-19. doi:10.1258/ jhsrp.2008.008016

20. Davis MM, Clark SJ, Butchart AT, Singer DC, Shanley TP, Gipson DS. Public participation in, and awareness about, medical research opportunities in the era of clinical and translational research. Clin Transl Sci. 2013;6(2):88-93. doi:10.1111/cts.12019
21. Trauth JM, Musa D, Siminoff L, Jewell IK, Ricci E. Public attitudes regarding willingness to participate in medical research studies. $J$ Health Soc Policy. 2000;12(2):23-43. doi:10.1300/J045v12n02_02

22. Kettis-Lindblad A, Ring L, Viberth E, Hansson MG. Genetic research and donation of tissue samples to biobanks. What do potential sample donors in the Swedish general public think? Eur J Public Health. 2006;16(4):433-440. doi:10.1093/eurpub/cki198

23. Mahmud A, Zalay O, Springer A, Arts K, Eisenhauer E. Barriers to participation in clinical trials: a physician survey. Curr Oncol. 2018;25(2):119-125. doi:10.3747/co.25.3857

24. Mopuru NR, Jose SP, Viswanath B, Kumar CN, Math SB, Thirthalli J. Factors influencing participation of psychiatry inpatients in clinical trials. Asian J Psychiatr. 2018;32:40-43. doi:10.1016/j. ajp.2017.11.021

25. Wong AR, Sun V, George K. et al. Barriers to participation in therapeutic clinical trials as perceived by community oncologists. JCO Oncol Pract. 2020;JOP1900662. doi:10.1200/JOP.19.00662

26. Comis RL, Miller JD, Aldige CR, Krebs L, Stoval E. Public attitudes toward participation in cancer clinical trials. J Clin Oncol. 2003;21 (5):830-835. doi:10.1200/JCO.2003.02.105

27. Dash C, Wallington SF, Muthra S, Dodson E, Mandelblatt J, AdamsCampbell LL. Disparities in knowledge and willingness to donate research biospecimens: a mixed-methods study in an underserved urban community. J Community Genet. 2014;5(4):329-336. doi:10.1007/s12687-014-0187-z

28. Jenkins V, Farewell D, Batt L, et al. The attitudes of 1066 patients with cancer towards participation in randomised clinical trials. $\mathrm{Br}$ $J$ Cancer. 2010;103(12):1801-1807. doi:10.1038/sj.bjc.6606004

29. Domaradzki J, Pawlikowski J. Public attitudes toward biobanking of human biological material for research purposes: a literature review. Int J Environ Res Public Health. 2019;16(12):2209. doi:10.3390/ ijerph16122209

30. Toccaceli V, Brescianini S, Fagnani C, Gigantesco A, D'Abramo F, Stazi MA. What potential donors in research biobanking want to know: a large population study of the italian twin registry. Biopreserv Biobank. 2016;14(6):456-463. doi:10.1089/bio.2016.0012

31. Wang SS, Fridinger F, Sheedy KM, Khoury MJ. Public attitudes regarding the donation and storage of blood specimens for genetic research. Community Genet. 2001;4(1):18-26.35. doi:10.1159/ 000051152

32. Arouri A, Al-Mahrouq S, Al-Ghazawi M, Russmann D. The evolving clinical research environment in Jordan. Regul Rapp. 2015;12:16-21.
Patient Preference and Adherence

\section{Publish your work in this journal}

Patient Preference and Adherence is an international, peer-reviewed, open access journal that focusing on the growing importance of patient preference and adherence throughout the therapeutic continuum. Patient satisfaction, acceptability, quality of life, compliance, persistence and their role in developing new therapeutic modalities and compounds to optimize clinical outcomes for existing disease states are major areas of interest for the journal. This journal has been accepted for indexing on PubMed Central. The manuscript management system is completely online and includes a very quick and fair peer-review system, which is all easy to use. Visit http:// www.dovepress.com/testimonials.php to read real quotes from published authors. 